\title{
Self-Employment Among North Korean Migrants
}

\author{
Marianne Jung
}

\begin{abstract}
In the absence of concrete ethnic differences, the division of a single Korean nation into two opposing states has led to the creation of specific types of nationhood and state building. This pseudo-ethnicity, which marks North Korean immigrants as "other" to South Koreans, results in adaptation problems and cultural difficulties. As the sociological literature considers selfemployment of minorities and immigrants to be an important avenue for upward economic mobility, this paper focuses on North Korean new settlers who have established their own businesses in South Korea. By case study analysis, it was revealed that new settlers and official organisations have highly differing perceptions on the issue of North Korean self-employment. Public authorities try to discourage North Koreans from becoming self-employed, which is why a comprehensive economic support programme is lacking. However, it was discerned that a new generation of new settlers is growing, showing high motivation and entrepreneurial spirit. The result of this study showed that a tailored support programme for self-employed North Koreans, such as an adapted form of social enterprises, is needed.
\end{abstract}

Keywords: South Korea, North Korea, migration, policies, immigrant business, self-employment, social-enterprise

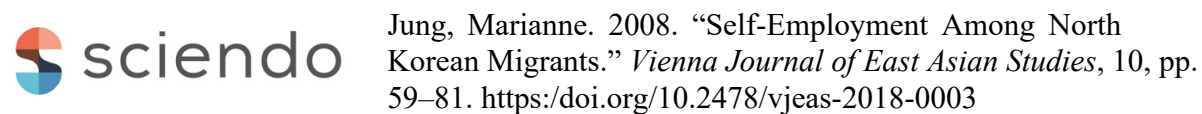




\section{Introduction}

Korea has been separated into two opposing governments since the end of World War II, and although cross-border movement is strongly prohibited, people have defected from North Korea ever since. The constitution of South Korea states that "the territory of the Republic of Korea shall consist of the Korean Peninsula and its adjacent islands." Therefore, all North Korean defectors who resettle in South Korea receive the South Korean citizenship. Various kinds of support and integration programmes are implemented to help North Korean immigrants to adapt into their new environment. After their arrival, North Koreans are expected to quickly get rid of their ethnic markers, such as North Korean accent and behaviour, and turn themselves into modern-subjects of South Korea (Choo 2006: 577). North Korean immigrants are considered to be a distinct ethnic-like group "other" to South Koreans, backward and underdeveloped, and on the basis of their pseudo-ethnicity, they are made into a socially marginalised minority group that faces major adaption problems in a highly-industrialised society (Choo 2006: 581). Basic misunderstandings and cultural difficulties have also been reported by both employers and employees at the workplace. However, while the number of defectors is steadily growing and their professional integration has become of high interest, literature focusing on the economic adjustment of North Korean new settlers remains limited (Bidet 2009: 158). Most of the literature concentrates on adaption experiences of North Korean migrants, with a focus on their social issues, social exclusion, or psychological traumata (Yun and Yi 2006; Kim 2010; Sŏl et al. 2014; Kim and Yang 2011; Jeon 2000 and Jeon et al. 2013). Studies assessing the level of basic vocational competencies and the current employment status, as well as on conflicts at the workplace are scarce (Yi et al. 2007; Cho and Jŏng 2006). Almost completely absent are any surveys on self-employed North Korean migrants. There has been a study by Yun In-Jin (2000) that investigated the characteristics and problems of North Korean business owners. Since both the social status and the age of North Korean migrants have changed, and the economic environment of South Korea has developed drastically, new studies are needed. Moreover, the self-employment of minorities is considered an important aspect for upwards economic mobility (Yun 2000; Sanders and Nee 1996; van Tubergen 2005). Therefore, this paper seeks to answer the following research questions: What are the particular challenges that North Korean migrants face when becoming self-employed? What economic policy measure should be implemented to assist their objectives?

First, the combination of various conditions, such as political, economic, and demographic that individuals face, needs to be studied as the basis for understanding the degree of adaption (Berry 2005). Therefore, an overview of orientation and 
settlement programmes for North Koreans is provided. Second, in order to understand the problems that self-employed North Koreans face, interviews with business owners and two expert interviews have been conducted. The result of the analysis will be presented, whereas an economic policy recommendation concludes this paper.

For romanisation, the McCune-Reischauer system will be used for Korean words, authors, and titles with one exception: for the names of Korean authors who have published their papers in English, their names are written as they appear in the original paper (Jeon, Woo Taek [= Chŏn, U-t'aek]). In general, the terms "North Korean (NK) migrants," "new settlers," "resettlers," or "defectors" will be used interchangeably. The term "new settlers" reflects the widely used term saet'omin 새터민 which is also the one North Koreans preferably use to refer to themselves. Other established terms are pukhani t'aljumin 북한이탈주민 and t'albukcha 탈북자, which can be both translated as "North Korean defector."

\section{Theoretical Background and Methodology}

Migration is usually accompanied by a radical change in the employment biography of individuals. Their human capital—such as education, qualifications, and knowledge - is usually hardly of any use in the country of destination (Sanders and Nee 1996). It is characteristic that immigrants are either employed in the areas of the labour market for which they have been recruited in their country of origin, or mainly work in those areas that are rejected by locals for various reasons (for example 3D jobs - dirty, dangerous, and demeaning blue-collar jobs) (Han 2010: 253). In industrialised countries we can observe that the labour market is split into the primary and secondary labour markets. While the former is characterised by stable working conditions, high wages, and career opportunities, low wages and poor and unstable working conditions characterise the latter. The theory of the "segmented labour market" assumes that locals mostly work in the primary labour market, while members of minorities and immigrants mostly work in the secondary one. Language problems and inexperience also aggravate the immigrants' chances in the primary labour market. The ethnic enclave economy, therefore, absorbs the cheap labour of immigrants in labour intensive production sectors (Han 2010: 263). By working in the secondary labour market, some immigrants want to escape ethnic discrimination and reach to higher income levels by means of self-employment, which is also the case with many North Korean migrants (see expert interviews below). According to empirical findings, self-employed migrants achieved higher income levels than migrants in dependent employment (Nee et al. 1994: 866). And since ethnic entrepreneurship fulfils a key economic and social role for ethnic communities (Walding- 
er et al. 1990:13 in Volery 2007: 30), this study looks at the issues that influence the establishment of immigrant businesses.

To reveal issues in self-employment, this research is based on case study analysis. Case studies are practical for data-based statements while four to ten cases are recommended (Borchardt and Göthlich 2009: 37). Data for analysis was generated by using the problem-centred interview method, which uses semi-structured communication strategies aimed at the representation of subjective problem perspectives (Witzel 2000). The subsequent analysis of the case studies is based on interviews which were conducted in April 2015, in person with self-employed North-Koreans in the metropolitan area of Seoul, South Korea. Interviewees were identified using snowball-sampling, common in ethnographic research, especially with 'hidden' or potentially marginalised communities (Bose 2012: 286). The interviewees were not reluctant to be tape-recorded since their identity whould be kept confidential—only their initials are used to refer to them. The interviews have been transcribed in Korean except one, which was conducted in English. As refugee interviews can be biased, additional material, largely publications to the related issue, as well as expert interviews were used to corroborate the interviewees' data.

\section{North Korean Defectors}

The numbers of North Korean defectors who reside in South Korea have exceeded the 30,000 mark, with between 1,500 to 2,500 newcomers every year, according to the Ministry of Unification.

Graph 1: Number of defectors in South Korea (arrival by year)

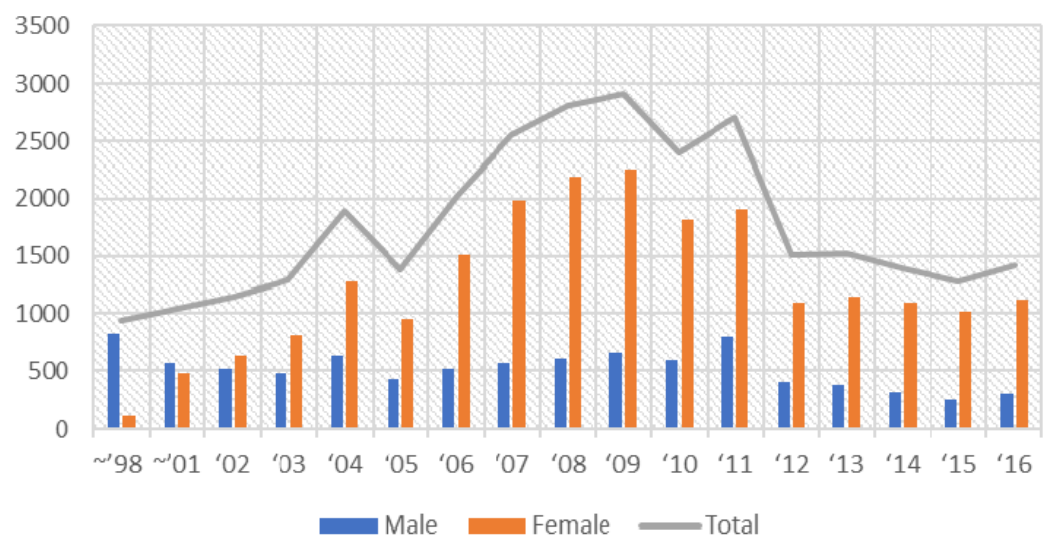

Source: Own-graph: Data provided online on the website of the Ministry of Unification. Estimation based on the number of North Korean refugees eligible for government settlement protection. 
Two thirds of the defectors flee from the Northern regions, such as North Hamgyŏngdo 함경도 close to the Sino-Korean border (Lankov 2006: 5). From there it is easier to enter China where they often search for sources of food and income. Most of them are workers, farmers, or housewives with their children. As the Chinese government does not grant them refugee status, the defectors begin their often long and dangerous journey towards a foreign embassy in China, or try to find a safe route to a neighbouring country such as Mongolia, Thailand, Cambodia, or Laos, where they can safely apply for refugee status (Courtland 2010: 16). If they get caught during their defection, they are subject to detention and deportation back to North Korea, where they face severe punishment and imprisonment. During the first years of separation between South and North Korea, it has been estimated that around 900,000 or ten per cent of the North Korean population fled to the South Korea. However, after the Korean War (1950-1953), the number of defectors decreased drastically. One factor was that the living standards between the two countries have been similar until the 1970s; another, because North Korea still had an effective border control. Therefore, until the 1990s, the number of defectors has been very low with five to ten defectors per year, consisting of the North Korean elite who took their chances when they occasionally had an opportunity to flee. Among other early defectors were pilots, diplomats overseas, elite soldiers, or fishermen who sailed to South Korea (Lankov 2006: 3-4). Since the mid-1990s, the total number of immigrants increased significantly due to the economic crisis in North Korea. Only from 2012 onwards has there been a drop marking North Korea's and China's policy to better secure the borders (Finney 2013). Graph 1 indicates that, since 2002, the numbers of women has exceeded that of men and represent about seventy per cent of the North Korean immigrants as of 2015.

\section{Quality of Life and Employment Status}

Academic studies on the quality of life of North Koreans are limited and somewhat dated. However, recent studies showed that North Korean defectors often suffer from acculturative stress and depression which is confidently related to their quality of life (Oh 2015). According to surveys, North Koreans generally seem to be satisfied with their life in Korea (Kim and Jang 2007: 6); out of 775 defectors, 60.5 per cent responded that they were satisfied with their life in South Korea and only 6.7 per cent stated they were not. This number, however, must not be interpreted as an indicator for successful integration in South Korea, but could also mean that, compared to their living conditions in North Korea or third countries, their life is better than before (ibid.). According to the source, making money is an urgent need of North Koreans who seek "economic betterment" (28.8 per cent). In a 2005 survey of the Database Centre for North Korean Human Rights, 22.7 per cent responded that they face economic difficulties, followed by "loneliness and isolation" (21.7 per 
cent), "health problems" (20.3 per cent), and "degradation of relative status and having nothing particular to do in South Korean society" (15.7 per cent). Other various problems were mentioned, connected to children's education, daily difficulties, lack of social life, etc., while 7.4 per cent stated they have no problems (ibid.: 8). Also work integration has shown to be difficult and unemployment rates are still high (Lankov 2015; Yi et al. 2007). The average monthly income of North Korean migrants is estimated to be almost half of the nationwide average and their unemployment rate $(9.7$ per cent) was three times higher than the nationwide level (Lankov 2015). According to evidence (Yi et al. 2007: 220), almost sixty-four per cent of the new settlers had received governmental aid for living costs. However, those numbers differ among the sources: up to eighty per cent who rely on governmental aid, with an unemployment rate between thirty and forty per cent (Bidet 2009: 160). Most refugees who arrived since the economic crisis in North Korea consisted of workers, farmers, housewives, and their children. Only few North Koreans (five per cent) were considered specialists, professionals, managers, administrators, or workers in the arts (Lankov 2015). Most North Koreans therefore work in simple menial labour in low-paid and unskilled jobs in the secondary labour market. They are prone to frequently changing their workplace and often face conflicts at work. Taking a closer look at their working situation, Chŏn et al. (2003: 163) revealed in their study that among 600 North Koreans, 47.9 per cent held a job, 27.5 per cent were unemployed, 16.5 per cent were students, 7.3 per cent housewives, and 0.7 per cent other. Among the working resettlers, 25.1 per cent held a regular job, 15.6 per cent a temporary job or were day labourers, and 7.2 per cent run their own business. When looking at their profession, among 273 workers, job experiences varied: manual labour ( 16.5 per cent), office workers ( 15.5 per cent), business salesman (15.5 per cent), industrial workers (13.0 per cent), restaurant business ( 8.5 per cent), delivery ( 6.0 per cent), and other. Almost thirty-nine per cent had no working experience. Furthermore, among eighty-two new settlers, 52.4 per cent stated they work for a small and medium enterprise (between five and fifty employees), and 4.9 per cent work for a bigger company with more than 1,000 employees (Chŏn et al. 2003 and Yi et al. 2007: 221).

Almost half of the new settlers that wish to become self-employed, attempt to run a restaurant specialising in North Korean foods, according to a survey among 185 interviewees conducted by the Korea Entrepreneurship and Management Research Institute (Lee 2015: 62).

\section{Adaption Problems and Traumata}

As mentioned, many defectors suffer from physical and mental illnesses (Wang et al. 2014; Marsella et al. 1994; Kim et al. 2008; Jeon 2000; Jeon et al. 2013). Most defectors faced shocking and confusing experiences both in North Korea and during 
the defection process, resulting in physical and mental exhaustion. A variety of traumatic events include severe hunger, malnutrition, and death of family members, as well as imprisonment or forced labour (Jue and Kim 2014). Some psychological problems are also related to a sense of guilt (e.g., for leaving behind their families) and persistent stress and anxiety during their flight or while staying in China (Jeon 2000). Symptoms of Post-traumatic Stress (PTS) disorders include self-destructive behaviours, depressed moods, insomnia, excessive alcohol consumption, recurrent nightmares, feelings of chest tightness, and back pain (Kim et al. 2008). It has been proven that the socio-political context of the refugee experience is also associated with the refugees' mental health. A worldwide study has observed that postdisplacement conditions have moderated mental outcomes, where worse outcomes were observed for refugees living in institutional accommodations and experiencing restricted economic opportunities. Also refugees of advanced aged, those more educated, and who suffer a loss of their pre-displacement socioeconomic status, had worse outcomes (Porter and Haslam 2005). Apart from mental health issues, many defectors have problems with adapting to the South Korean society in general. According to surveys, it was shown that many migrants have difficulties to get close to South Korean people, due to their low economic standing, cultural differences, and lack of assurance that they would be accepted (Jeon 2000: 365). One particular difference lies in the way of thinking. South Koreans have been described by new settlers as very individualistic, reflected in this citation by a North Korean student: "In clean-up time in North Korean schools, students who have finished their work earlier usually help others. But in South Korean schools, students who have finished their work earlier play together. At first, it was very strange to me" (Jeon 2000: 365). On the other hand, South Koreans consider the North Koreans as backward and under-developed. They expect them to get rid of North Korean ethnic markers, such as their accent or clothing style, and turn themselves into modern subjects of South Korea (Choo 2006: 577). In fact, many young North Koreans are facing difficulties with language, making friends, school, and finding a good job. But also the South Korean market system puts a lot of stress on the defectors. Mass production, mass consumption, and aggressive advertisement pose new kinds of challenges to them. Due to the lack of knowledge, many defectors lack the competence to manage money, or make savings from their incomes. As a result, many have become confused and distrustful (Sohn 2013).

\section{Settlement Support}

Since the number of defectors used to be small during the first decades of separation, the South Korean government treated North Korean defectors quite generously. In 1962, South Korea passed the 'special law on protection of defectors of North Korea,' revised in 1978, which remained effective until 1993. The defectors were 
provided with generous benefits and free housing (about KRW 35 million / approx. $€ 27,000)^{1}$ which almost granted lifelong material security (Lankov 2006: 9; Jeon 2000: 366). Defectors were rewarded for their defection and treated as "freedom fighters following the righteous path." However, when the number of defecting North Koreans increased in the mid-1990s due to a great famine in North Korea, the laws concerning defectors were amended in 1993 and the financial support was reduced to average KRW 14 million (approx. €10,700) (Jeon 2000: 366).

The 1997 Act on the Protection and Settlement Support of Residents Escaping from North Korea (Article 1) stated as its purpose to promote the "protection and support necessary to help North Korean escapees from the area north of the Military Demarcation Line and desiring protection from the Republic of Korea, as swiftly as possible in order to adapt and stabilize, all spheres of their lives, including political, economic, social and cultural" (Courtland 2010: 16).

This act was amended in 2010 and resulted in the creation of the North Korean Refugees Foundation (NKRF), now better known as Hanawŏn 하나원, a settlement support centre for integration (Bidet and Jeong 2016). Its purpose is to ensure the identity of the defectors they are taken under custody, usually by the National Intelligence Service and the Ministry of Unification, where they are isolated and interrogated by the authorities (Lankov 2006). This is to verify that defectors are neither North Korean agents nor Chinese citizens who frequently try to obtain the much desired South Korean citizenship. Then the immigrants are sent to Hanawŏn, where they receive basic social orientation for a period of three months. The training takes twelve weeks with a 420-hours programme:

- Forty-six hours for improving emotional and physical health (including psychological tests and counselling, sports training)

- 121 hours for acquiring an understanding of the South Korean society (teaching on history, market economy, culture, law, on site learning)

- 174 hours of support for career planning and job search (including shortterm intensive vocational training)

- Fifty-one hours focused on teachings related to support programmes

Additionally, they can choose from elective and supplementary programmes offered by the institution. Emphasis is clearly put on the career guidance and job training with 174 hours. The "Hope for Work" programme was designed to help participants improve their skills and assist them in obtaining employment, including training on how to write a résumé, etc. Since 2013, gender-specific vocational training is offered as well, where participants can have a direct experience on up to twelve different jobs during their stay in Hanawŏn (White Paper 2014: 189-190). A job fair is being

\footnotetext{
${ }^{1}$ April 5, 2018: EUR 1 = KRW 1299.41 (rounded to KRW 1,300).
} 
held once a month, where the refugees are offered to be interviewed and encouraged to send their curriculum vitae to Small and Medium enterprises (SME). Coupled with the fair are visits to SMEs, where participants can become familiar with the South Korean working culture. For those who completed the regular programme, it is possible to attend intensive courses at the second Hanawon branch on job qualification or re-education for graduates. Emphasis is put on using skills which have been obtained in North Korea and/or to earn new certificates of qualification. Furthermore, the second Hanawŏn offers social orientation classes for male North Koreans, giving emphasis on vocational training as well as South Korean language. Short-term vocational training is offered for automobile maintenance, welding, and forklift operation (White paper 2014: 197).

In summary, the first Hanawŏn provides a twelve-weeks basic social orientation programme covering various fields, whereas the second Hanwŏn branch provides intensive and vocational training. After completion, North Korean new settlers receive housing and a basic settlement benefit depending on the size of the household. Moreover, they receive a quarterly payment for one year after moving to the new residence. Since 2012, the amount for a single household totals KRW 7 million (approx. €5,355), of which three million are paid in instalments. The housing subsidy amounts additionally to KRW 13 million (approx. $€ 10,000$ ), which is quite a lump sum. Additional benefits can be applied to those over sixty-years old of age, disabled people, those who need long-term medical treatment, as well as children of single parent families (White paper 2014: 201-203).

\section{Employment Support}

Financial benefits are bestowed upon those who continuously work at the same job, receive vocational training, or obtain certifications of qualification. The incentive programme for those staying at the same job for at least one year or more began in 2005 and grants up to a maximum of KRW 5.5 million (approx. €4,207) employment incentive. Since 2013, the incentives have been increased for those employed outside of the Seoul metropolitan area. These incentives are intended to help North Korean new settlers to become economically self-sufficient, instead of relying on the national basic livelihood security system. A maximum of KRW 21.1 million (approx. $€ 16,000)$ is possible if one has completed the Hanawŏn programme, trained at a vocational institute, obtained a certificate of qualification, and found and maintained a job for more than one year (White paper 2014: 203-204). Not only are the defectors encouraged to find a job, but enterprises are also supported when they hire a North Korean worker, with subsidies of up to fifty per cent of the employees' salary can be granted (ibid.: 205). The employment support centre was set up in 2012, offering support to social enterprises that employ immigrant workers or help refugees to start their own small business. There is also micro-financing available by the 
Hyundai Motor Group Smile Microcredit Bank, which opened its doors for microfinance in cooperation with the Ministry of Unification. The micro-credits and loans are accompanied with consulting and entrepreneurial education for incubating startups (Hyundai Smile 2015).

\section{Educational Support}

Under certain conditions North Korean refugees enrolling at a national or public university are exempt from admission fees, tuition, school operation, or boarding fees for eight semesters. At private universities they are usually completely exempt from tuition, however this tuition subsidy can be discontinued if the students fail to reach at least seventy per cent of the highest possible GPA in the previous two semesters (White paper 2014: 208). The government placed fifteen coordinators in schools and regions with a high number of North Korean young refugees in order to assist them at home, at school, and in the community. The North Korean Refugees Foundation supports home-study workbooks and distance-learning English programmes. Various educational opportunities are offered. For example, WEST (Work, English Study and Travel) is a joint Korea-USA study and work programme that offers opportunities of internships in the USA for up to eight months (ibid.).

\section{Support at Place of Residence}

There are various networks and regional councils at the local government level to support the new settlers after their twelve-week programme at Hanawŏn. Various specific programmes in order to help settling in the region are developed and executed and social workers in regional adaption centres, called Hana Centres, support the new settler with personalised follow up programmes at their new place of living. They offer assistance in understanding the local community and in daily life matters. For example, they go to banks, hospitals, or markets, visit local vocational training institutes, as well as potential employers. Support workers of local bodies offer counselling and guidance (White paper 2014: 210-211). I have visited and conducted an expert interview at one of those Hana Centres (see Expert Interviews below).

In conclusion, this literature review demonstrated that North Korean new settlers have difficulties in adapting to South Korean society, which is reflected not only in their high unemployment rate and their health problems but also by the variety of support programmes that were initiated to help them start a new life in South Korea. I was able to meet with a handful of North Korean migrants. I visited a high-school for North Koreans (Y̌̌myŏng hakyyo 여명학교), talked to their teachers, and had lunch with the students to get a better understanding of their situation. Also, I conducted semi-structured interviews with four North Korean business-owners; the results of the analysis are presented in the following section. 


\section{Case Study Analysis}

This section presents the results of the case-study analysis. Yun's publication (2000) on the characteristics of twenty-five self-employed North Korean defectors was used as comparison, as well as to show the changes that occurred over time. Data was acquired using the problem-centred interview method by Andreas Witzel (2000). The interviews have been conducted, recorded, and transcribed in Korean, with one exception which was conducted in English. In general, the interviews lasted between one and two hours and took place within the Seoul metropolitan area in April 2015.

Table 1: Informants

\begin{tabular}{|l|l|l|l|}
\hline Person & In SK since & Educational level & Business details \\
\hline $\begin{array}{l}\text { Mr. P } \\
\text { (age 33) }\end{array}$ & 2004 & $\begin{array}{l}\text { University degree } \\
\text { in SK }\end{array}$ & $\begin{array}{l}\text { Two Social Enterprise Coffee Shops in Seoul - the } \\
\text { employees own stocks of the company. }\end{array}$ \\
\hline $\begin{array}{l}\text { Ms. L } \\
(38)\end{array}$ & 2003 & $\begin{array}{l}\text { University degree } \\
\text { in SK }\end{array}$ & $\begin{array}{l}\text { Trading business with gift articles within the Seoul } \\
\text { metropolitan area; 6 employees (2 from North Korea). }\end{array}$ \\
\hline $\begin{array}{l}\text { Ms. Y } \\
(26)\end{array}$ & 2006 & $\begin{array}{l}\text { University degree } \\
\text { in SK }\end{array}$ & $\begin{array}{l}\text { Live-stock farm located in Kyonggi-region, selling } \\
\text { chicken eggs in Seoul; established in cooperation with } \\
\text { three colleagues. No staff. }\end{array}$ \\
\hline $\begin{array}{l}\text { Mr. K } \\
(28)\end{array}$ & 2010 & $\begin{array}{l}\text { Secondary school } \\
\text { in North Korea }\end{array}$ & $\begin{array}{l}\text { Trading business with products made of wild roses } \\
\text { grown in Kangwon-region. No staff. }\end{array}$ \\
\hline
\end{tabular}

\section{Social Background}

According to Yun (2000), defector business owners show selective demographic and socio-economic characteristics. In Yuns' sample of twenty-five defector business owners, the study participants were all male, the mean age was forty years-old and half of them were married. In general, they worked in managerial positions in North Korea and held higher education qualifications (Yun 2000: 157; 286). My cases show a different picture and underline the fact that, since 2002, female defectors outnumber the male ones. My interviewees have arrived in South Korea between 2005 and 2010, at a young age, and three of them have not yet been married when they were interviewed. Regarding to gender, I have interviewed two male and two female business owners. While three of the interviewees have been educated at a high-school for young North Korean defectors, the same ratio indicated university education as well. Three of the four started their business without relying on an experienced partner, and all of them had direct and/or indirect experience of running a business in North Korea. They engaged in barter trade and/or raised and sold live animal stocks, such as pigs or fish, or they traded Chinese products at the informal market. In the sample by Yun, forty per cent had experience with business in North Korea. These numbers may be even higher these days, since my interviewees told me that many in their vicinity were directly or indirectly involved in trade- 
otherwise, surviving would have been difficult. Comparing this sample to Yuns' interviewees, we can tell that in the last twenty years, the social background of North Koreans immigrants has changed considerably.

\section{Motives to Enter the Private Sector}

Seeking financial independence, many North Korean new settlers consider running their own business in face of competitive employment barriers (Lee 2015; Yun 2000). It should be noted that the ratio of self-employment in South Korea is greater than in other OECD countries. Motives are often induced by push-factors, that is, involuntarily during economically difficult times and higher unemployment rates (Kim and Cho 2009). In Yuns' sample, the main motivation of North Koreans to enter the private sector was their disadvantaged status in the South Korean labour market. They had difficulties in finding a job, sought prospects of higher earnings, or just wanted to be their own boss, which is also confirmed by the 'segmented labour market' theory. My interviewees revealed that there is also a new generation growing that is seeking social change, eager to shape a reunified future. The interviewees said that they "want to help other defectors," "prepare for reunification," and work out "role-models of business." The result may also be different, due to the open interview method which allowed a lot of self-expression, unlike standardised surveys.

The motives for self-employment and the willingness for social change are reflected in the following examples:

Mr. P used to visit a social enterprise coffee shop which employed North Korean defectors. He watched them work and recognised that they do not work efficiently. "They missed some kind of drive," he said. He was wondering about it and thought this might be due to the fact that they do not own the business. That is when he thought: "I will do it differently," and opened his first coffee shop, where his North Korean employees are shareholders of the business. His employees had to buy those shares with their own money. Mr. P's dream was to help other defectors rather than opening a coffee shop, which was used as a medium to reach that goal. Mr. P lets his co-workers think for themselves and tries to give them as much responsibility on business planning and execution power as possible.

Ms. Y stated that, among other reasons, one motivation for getting self-employed was that, although young North Korean defectors adapt more easily to South Korean society, the elder generation is having a hard time and face loneliness and poverty. Ms. Y's idea was to start a business which could be used as a role model, where the young and the older North Koreans can work together. She said that everyone lives for oneself in South Korea and, although there are so many organisations and networks in the South, there is a lack of anticipation at the human level. After reunifica- 
tion, she wants to go to North Korea and apply the knowledge she gained to teach North Koreans.

The other two interviewees did not state a social reason but economic ones, such as business opportunities. Although Mrs. L had a "safe" job as a social worker (she holds a bachelor degree in social work) she decided to become self-employed with the help of her husband who runs his own business as well. She now employs six workers at her company, two of whom are North Korean new settlers. Mr. K's case was rather unique; he arrived in 2010 and started studying global business, but he quickly dropped out after one semester. He has never worked as an employee before but engaged in various trading businesses with partners. While doing so he came across an opportunity and established his start-up in August 2014. He is selling various products made of wild roses, which he cultivates in Kangwŏndo (a province in north-east South Korea), such as beauty products and food stuffs.

\section{Findings}

North Korean migrants find it difficult to secure financial resources, they lack business networks, business skills, and experience in various areas (Lee 2015; Yun 2000). This can be confirmed by this sample as well. All four interviewees had weak business networks and relied heavily on church networks. Although the Protestant community represents a powerful system in South Korea with influential members in politics and economy, North Koreans lack personal connections (inmaek 인맥) that are especially important in Korean society. Those personal connections are based on kinship as well as regional and school ties. A lack of connections results not only in lowering the chances of borrowing money through informal networks, but also keeps people disadvantaged in terms of securing information and knowledge (Yun 2000). It was difficult for my interviewees to receive a loan from a bank, supposedly because "they do not trust us and think that we know nothing about capitalism." Mr. K showed a great deal of understanding, because he heard that some North Koreans took the borrowed money and ran away to third countries, which is why he proposes business investment instead of loans. Starting with no financial support, it was difficult for Ms. Y to set up her livestock business right after graduation. She said:

People don't encourage us to do a business because it is risky; to be employed is safer. South Koreans rather go the safe path and don't try anything risky. But we, North Koreans, experienced much hardships and when we try something we give it a lot of effort. South Koreans also get a lot of support, but we don't get anything, so trying is much harder for us than for them. 
According to her opinion, she and her partners could not receive financial support as they did not study agriculture as their major. She pointed out that, if they would have done so, they could have been eligible to receive a maximum of three hundred million Won (approx. €231,000). Ms. Y further complained that, although there are many organisations and foundations to seek financial support, it is difficult to meet the requirements. However, they have a mentor who helped them rent some land and that is how they started small. So, both obtaining financial capital and finding customers was very difficult - most of the sales are made in church and related networks. Currently they are preparing to become a social enterprise; however, in order to obtain certification by the government, and thus receive subsidies, they have to pay at least one employee salary for a minimum of six months. At the moment that was not affordable. What she wishes from the government is a support programme, which is more flexibly tailored to the needs of applicants. Also she mentioned the need of business related training. At that point, she emphasised that it is important that North Korean immigrants get proper training to intermediate between the South and the North. As they have lived in both societies and know both cultures, it is important to foster talents as an asset for the future.

Also Mr. K expressed his wish for a business role model that he could follow, as well as a mentor or expert on his side. According to Mr. K, there are support channels provided by the government; however, he confirmed Ms. Y's statement that it is very difficult to meet their requirements. Once he had finished preparing the application for funds, he complained, the business opportunity was long gone - or the date for support application and the date for the project did not match. He furthermore criticised that the government proclaims a "creative economy," but that they are not innovative at all, making South Korea always a follower instead of an innovative leader: "I doubt that the government has a business-oriented mind, it takes them too long to recognise something as innovative. Only when they see something works out well they decide to do it; but that is too late. That is why we need a better judgement." Mr. K also mentioned that South Koreans have no 'challenge spirit' (tojŏn chŏngsin 도전 정신) and do not like to take any risks. There are so many restrictions in South Korea, he complained, but once he overcomes the transition period, he is positive that he will expand his business "tremendously." Mr. P also told me of similar experiences. He explained to me that those North Koreans who came to the South were risk takers, but people kept telling them to find a "safe" job. He said that this was some kind of "South Korean propaganda" and, after three years of being exposed to it, North Koreans only think about getting a safe job. But Mr. P strongly criticised this mindset, emphasising that North Koreans are innovative, flexible, and adventurous, and should use their abilities to become self-employed. What is lacking, he complained, are networks and funds. The South Korean system discriminates against North Koreans when it comes to getting loans and, although it is possible to apply for Social Enterprise status, it involves a lot of 
bureaucracy, he said. His coffee shop, for example, is a Social Enterprise joint-stock company, but it took a lot of effort and knowledge for establishment. In fact, he had established the coffee shop as a co-operative ${ }^{2}$ but he recognised that the North Koreans were not yet able to take full responsibility, since in North Korea they were never able to learn decision making on a broader basis. That is why he started with a stock-company. However, he wants to establish co-operatives in the future. Very interestingly, he said that co-operatives are the most democratic form of doing business; doing a co-operative, he argued, is the best form to learn about democracy after coming out of an autocratic system. He further criticised that there are support programmes for businesses and micro-businesses, but not for North Korean start-up organisations. Mr. P further pointed out that the government invests more than eighty billion Won for reunification and more than twenty-six billion Won of resettlement funds per year. However, there is no support programme for North Korean start-ups, as he said. In general, the support for small and medium enterprises is not developed enough, and he further emphasised that there should be a kind of Silicon Valley in South Korea, where basic conditions for a business are given.

Only Mrs. L had no such problems. In fact, she speaks with a perfect South Korean accent and not even her own children know that she came from the North. She said she had never experienced any discrimination while doing business or when receiving a loan from the bank. Like many business owners, she faces difficulties in finding customers, but she uses church networks. Most of the items are therefore sold within the Christian community. Mrs. L said that, if the government would provide subsidies, they would easily get lost; therefore, it is important to have experienced business people as mentors to learn from them directly. Mrs. L emphasised that North Koreans have to learn that doing business is something difficult in SK and that they must have working experience at least for five years before opening their own business. That is why, she further emphasised, education and consulting on market research, accountings, tax law, and business related information is needed.

Answering our first research question, it was revealed that the interviewees had weak business networks apart from church networks. Three of the four interviewees highlighted that the wish to become self-employed is being discouraged by South Koreans, who suggest working in dependent employment. They also complained about economic support programmes: the existence of "so many restrictions"; that it is "difficult to meet the requirements"; that the "application dates do not match business opportunities"; or "the major does not match the business." Also, the request for business consulting, including a training programme and a business

\footnotetext{
${ }^{2}$ A co-operative is an autonomous association of persons united voluntarily to meet their common economic, social, and cultural needs and aspirations through a jointly owned and democraticallycontrolled enterprise: http://ica.coop/en/what-co-operative (accessed June 9, 2015).
} 
mentor, was articulated. It was also interesting that the interviewees, independently of one another, pointed out that they are willing to accept challenges and risks contrary to South Koreans.

\section{Expert Interviews}

Expert interviews were conducted since it is important to understand the perspectives and interests of service providers, as well as to corroborate my data. One interview was with Mrs. Kim, a social worker at the community association Hana Centre, and one with Mrs. Cho, who founded the Yŏmyŏng high school for young North Korean defectors.

Mrs. Kim works at a branch of the Hana Centre which provides services to North Korean defectors at the community level. When talking with Mrs. Kim about the economic situation of North Korean resettlers and why they are not encouraged to establish a start-up business, she answered that many North Koreans experience a lot of stress when working as salary workers due to cultural differences. This is a major reason why many North Koreans want to become self-employed and open their own business. However, she emphasised, they do not know how difficult it is, especially during the times of global economic regression. That is why governmental agents try to convince the defectors to work as employees and encourage them to get to know the South Korean society better before establishing a start-up. When mentioning to support the defectors with their ideas, Mrs. Kim strongly rejected that thought, stressing that most of them go bankrupt in no time: "we discourage them a lot to become self-employed and try to convince them to become an employee." That is why incentives are given to employees that stay on their job (see employment support above). Still, Mrs. Kim said that the new settlers have more strengths and talents than they knew they had. Mrs. Cho, the Vice-President and founder of the Yŏmyŏng high school for young North Korean defectors, voiced similar worries as Mrs. Kim: "only a few defectors become successful with their business and those whom you met have just started with their business." Those who become more or less successful are usually working in those areas in which South Koreans do not like to work, such as woman divers (haenyo 해녀) or farmers, Mrs. Cho stated. There was a time, she said, where the government gave more support for establishing their businesses; however, as the number of failing businesses rose, they stopped offering such support. The problem was that North Koreans just produced their goods or ran their restaurant, but did not focus on customer relations. That is because they have never lived in a customer-oriented market and do not understand its importance in a capitalist society: "it is not enough to be a good cook-it takes more than that," she argued.

In conclusion, both Mrs. Kim and Mrs. Cho argued that it is not advisable to support the self-employment of North Korean migrants due to their lack of 
knowledge of the South Korean society, as well as how economical dynamics function. Hence, at Hana Centre, social workers discourage those defectors who say that they want to be self-employed.

\section{Recommendation: An Adapted Form of Social Enterprise}

As the case studies have revealed, a new generation among new settlers is seeking social change. The fact that North Koreans are willing to accept challenges and risks, contrary to South Koreans, was a recurrent pattern in my interviews. The following section is devoted to the second research question, that is, what economic policy would assist North Koreans who wish to become self-employed. On the one hand, this might be an important step to reduce their failure rates; on the other hand, it would correspond to the needs of North Koreans who want to shape their future by being self-employed. As the interviews revealed, there is a need for business consulting, including a training programme, a mentoring programme, and better business networks. In South Korea, Social Enterprises enjoy a special status among other forms of businesses. If they get registered and approved by a special committee under the Ministry of Labour, the state offers financial subsidies for initial capital, various tax benefits, support in consulting on business administration, and preferential purchase by public institutions (table 2).

Table 2: Means of Support

\begin{tabular}{|c|}
\hline Tax relief and other forms of support measures \\
\hline $\begin{array}{l}50 \% \text { Tax relief for social enterprises during the first four years } \\
\text { During the first two years, the government covers all labour costs and social security } \\
\text { contributions related to the created jobs }\end{array}$ \\
\hline Operation support \\
\hline $\begin{array}{l}\text { The Korean Minister of Labour provides support, such as specialised advice, information, } \\
\text { etc. in areas of administration, technology, tax, labour, accounting, etc. } \\
\text { The central or local government may support or finance site expenses, facility expenses, } \\
\text { etc., or lease state-owned and co-owned land, which is necessary for the establishment or } \\
\text { operation of a social enterprise }\end{array}$ \\
\hline Public Relations \\
\hline $\begin{array}{l}\text { Support provided by the government: } \\
\text { 1) Raising awareness among the public } \\
\text { 2) Establishing local government offices for the support of social enterprises } \\
\text { 3) Supporting the cooperation between businesses, research agencies, and social enterprises }\end{array}$ \\
\hline Public Procurement \\
\hline $\begin{array}{l}\text { The government and public institutions shall promote the prior purchasing of goods and } \\
\text { services produced by a social enterprise }\end{array}$ \\
\hline Education and Training \\
\hline $\begin{array}{l}\text { The government shall promote the establishment of training institutions for social enter- } \\
\text { prises }\end{array}$ \\
\hline
\end{tabular}

Source: Social Enterprise Promotion Act 2008. 
These support strategies, provided by the Korea Social Enterprise Agency for social entrepreneurs, would also match the interviewees' request for a mentoring programme with specialised courses and customised education for social enterprise start-ups. Also, as most of the interviewees had weak business networks, the preferential purchase system by public institutions would be of great help, as well as the support of networks between businesses and others.

Such a tailored support programme holds great promise for a lasting and transformational benefit to self-employed North Koreans. However, it was revealed that it is very difficult to obtain such a certification by the government. Strict certification requirements reflect the emphasis that the government puts on job creation (see table 3). Also, it is known that the application procedure is highly time-consuming and requires a lot of in-depth knowledge. Therefore, it is recommendable to adapt the existing form of Social Enterprises, adjusted to the needs of North Korean business founders. This would allow the governmental agencies to allow the migrants to be self-sufficient (which is highly discouraged at the moment) while keeping some control over "their protégés."

In fact, Social Enterprises were established as a response to rising problems of welfare states and markets (Park 2009). While they are seeking economic profits like a regular business, they provide social services and/or jobs to vulnerable social groups. North Korean migrants are also a vulnerable social group, facing disadvantages in both society and the regular job market, which is why the "social enterprise support programme for North Korean refugees" has been implemented, targeting work integration in dependent employment (Bidet and Jeong 2016). Apart from that, it has been difficult for self-employed North Koreans to apply for Social Enterprise status. Ms. Y and others stated that it was difficult to meet the requirements represented in table 3.

An applicant enterprise may choose between one of various organisational types, such as a corporation, NPO, or co-operatives. Also a social goal must be indicated, such as job creation for a disadvantaged social group (disabled persons, integration of people with difficulties) and/or social service type (services for the sick, elderly, environmental services, childcare, etc.). However, it does not take into account that the self-employment of a vulnerable social group, such as North Koreans that face disadvantages in the job market, might be a desirable social goal as well. 
Table 3: Social Enterprise Certification Requirements

\begin{tabular}{|c|c|}
\hline Criteria & Certification requirements \\
\hline Organisational Type & $\begin{array}{cl}\text { A Social Enterprise may choose between: } \\
- & \text { Corporation or cooperative } \\
- & \text { Public corporation } \\
- & \text { Non-profit civic organisation } \\
- & \text { Social welfare corporation } \\
- & \text { Living cooperative } \\
- & \text { Other non-profit organisations } \\
\end{array}$ \\
\hline Paid Employees & $\begin{array}{l}\text { The job creation for at least one paid employee other than volun- } \\
\text { teers or unpaid members is necessary for approval }\end{array}$ \\
\hline $\begin{array}{l}\text { Income from business } \\
\text { activities }\end{array}$ & $\begin{array}{l}\text { Six months prior to the application, the income from business } \\
\text { activities should already exceed } 30 \% \text { of the wages }\end{array}$ \\
\hline Social Goals & $\begin{array}{l}\text { Social Enterprises need to show the following aspects: } \\
\text { - Job creation type: more than } 30 \% \text { of hired employees } \\
\text { must be socially disadvantaged individuals } \\
\text { - Social service type: should provide more than } 30 \% \text { of } \\
\text { its total services to the socially disadvantaged } \\
\text { - Mixed type: more than } 20 \% \text { for hiring and social provi- } \\
\text { sion for the socially disadvantaged } \\
\text { - Local Community Contribution type: more than } 20 \% \\
\text { for vulnerable social groups residing in the relevant re- } \\
\text { gion } \\
\text { Other types: main purpose is to provide social services, } \\
\text { but realisation is hard to judge with ratio of employ- } \\
\text { ment or service provision }\end{array}$ \\
\hline Governance & $\begin{array}{l}\text { Employees or service clients should participate in the decision- } \\
\text { making process }\end{array}$ \\
\hline
\end{tabular}

Source: adapted from Park 2009: 12; Website KOSEA; Social Enterprise Promotion Act 2008.

Meeting requirements is a serious obstacle for approval: at least one paid employee must be employed already, and six months prior to the application the income from business activities should already exceed $30 \%$ of the wages (see table 3 ). This is a difficult task and it was the reason Ms. Y could not apply for Social Enterprise status. Her income did not allow her to employ other workers, so she has to wait until profits are high enough to enjoy the benefits and gain the skills she needs to run a profitable business. This is why the Social Enterprise policy should indicate the selfemployment of North Koreans as a social goal.

\section{Conclusion}

Reading and interpreting the interview results it was discerned that new settlers and official organisations have highly differing perceptions on the topic of North Korean self-employment. The government bestows high financial benefits on those who continuously work at the same job and receive vocational training in order to be- 
come economically self-reliant. Also, all businesses (not only Social Enterprises) are supported when they hire a North Korean worker through subsidies of up to fifty per cent of the employee's salary. North Koreans who plan to become self-employed are however discouraged to do so. Hence, a support programme, including educational and financial support which would enhance their chances of upward economic mobility, is lacking. It was furthermore revealed that a new generation among new settlers is seeking social change and that they are eager to shape their future, especially in the wake of a reunited Korea. As social entrepreneurship is an appealing idea, holding great promise for a lasting benefit to society, it is recommended to adapt the existing form of the Social Enterprises that, in the first place, were established as a response to rising problems of welfare states and markets (Park 2009). Such a flexibly-tailored support programme would not only help North Korean immigrants to become self-reliant, but could also secure investment and foster integration into South Korean society.

In conclusion, it was observed that the new settlers showed high levels of motivation and ability to make a self-employed living and to use their knowledge for others. The North Korean migrants' in-depth knowledge of North and South Korean society are key assets for future reunification. It is therefore recommended that there be an implementation of a more flexibly-tailored support programme for selfemployed North Koreans.

\section{REFERENCES}

Aldrich, Howard E. and Roger Waldinger. 1990." Ethnicity and Entrepreneurship." Annual Review of Sociology, 16, pp. 111-135.

Berry, John W. 2005. "Acculturation: Living Successfully in Two Cultures." International Journal of Intercultural Relations, 29, pp. 697-712.

Bidet, Eric. 2009. "Social Capital and Work Integration of Migrants." Asian Perspective, 33 (2), pp. 151-179.

Bidet, Eric and Bok Gyo Jeong. 2016. "Social Enterprise and Work Integration of North Korean Migrants in South Korea." Contemporary Politics, 22 (4), pp. 395-411.

Borchardt, Andreas and Stephan E. Göthlich. 2009. "Erkenntnisgewinnung durch Fallstudien." In Sönke Albers, Daniel Klapper, Udo Konradt, Achim Walter, and Joachim Wolf, eds., Methodik der empirischen Forschung. Wiesbaden: Gabler Verlag, pp. 33-48.

Bose, Pablo S. 2012. "Mapping Movements: Interdisciplinary Approaches to Migration Research." In Carlos Vargas-Silva, ed., Handbook of Research Methods in Migration. Cheltenham: Edward Elgar Publishing Limited, pp. 273-294.

Cho, Jŏnga 조정아 and Jŏng Jin-kyŏng 정진경. 2006. “Saet’ŏmin'ǔi ch'wiŏp'kwa chikchang saengwal kaldŭng'e kwanhan yŏn'gu 새터민의 취업과 직장생활 갈등에 관한 연구 [A Study on Conflicts in Workplace of North Korean Refugees]." T'ongil chŏngch'aek yŏn'gu 통일정 책연구 [Unification Policy Research], 15 (2), pp. 29-52.

Choo, Hae-yeon. 2006. "Gendered Modernity and Ethnicized Citizenship: North Korean Settlers in Contemporary South Korea." Gender and Society, 20 (5), pp. 576-604. 
Chŏn, U-t'aek [= Jeon, Woo Taek] 전우택, Yun Tŏg-yong 윤덕용, and Ŏm Chin-sŏp 엄진섭. 2003. “T'albukchadŭr'ŭi namhan sahoe chŏgŭng saenghwal silt'ae chosa 탈북자들의 남한사회 적응생활 실태조사 [Survey Results of Adaption and Life of North Korean Defectors in South Korea]." T'ongil yŏn'gu 통일 연구 [Journal of Unification Studies], 7 (1), pp. 155-208.

Courtland, Robinson. 2010. "North Korea: Migration Patterns and Prospects." Nautilus Institute, November 4, 2010. Online: http://nautilus.org/napsnet/napsnet-special-reports/north-koreamigration-patterns-and-prospects/ (accessed: November 9, 2015).

Finney, Richard. 2013. "China Extends North Korean Border Fences to Bolster Security." Radio Free Asia, August 5, 2013. Online: http://www.rfa.org/english/news/korea/fences08052013162858.html (accessed: May 20, 2015).

Han, Peter. 2010. Soziologie der Migration. Stuttgart: Lucius \& Lucius

Hyundai Smile 2015. Online: https://www.hyundaismile.or.kr/index.html or http://www.saramin.co.kr/zf_user/company-info/view/csn/1018218906/company_nm/ (사)현 대차미소금융재단 (accessed: November 9, 2015).

Jeon, Woo Taek. 2000. "Issues and Problems of Adaptation of North Korean Defectors to South Korean Society: An In-depth Interview Study with 32 Defectors.” Yonsei Medical Journal, 41 (3), pp. 362-371.

Jeon, Woo Taek, Jin-Sup Eom, and Sung Kil Min. 2013. "A 7-Year Follow-Up Study on the Mental Health of North Korean Defectors in South Korea.” Journal of Traumatic Stress, 26 (1), pp. $158-164$.

Jue, Juliet and Hyunjin Kim. 2014. "Draw-a-Story Response Characteristics of Young North Korean Defectors." The Arts in Psychotherapy, 41, pp. 504-510.

Kim GiSeung and Joonmo Cho. 2009. "Entry Dynamics of Self-employment in South Korea". Entrepreneurship and Regional Development, 21 (3), pp. 303-323.

Kim, Hyŏn-gyŏng 김현경, Ŏm Chin-sŏp 엄진섭, and Chŏn U-t'aek [= Jeon Woo Taek] 전우택. 2008. "Pukhani t'aljumin'ŭi oesang kyŏnghŏm ihu simni'jŏk sŏngjang 북한이 탈주민의 외상 경험 이후 심리적 성장 [Post-traumatic Growth Among North Korean Refugees]." Sahoe pokchi yŏn'gu 사회복지연구 [Korean Journal of Social Welfare Studies], 39, pp. 29-56.

Kim, Jih-Un and Dong-Jin Jang. 2007. "Aliens Among Brothers? The Status and Perception of North Korean Refugees in South Korea.” Asian Perspective, 31 (2), pp. 5-22.

Kim, Jong-gyŏng 김종경 and Yang Yŏng-hŭi 양영희. 2011. "Pukhani t'aljumin'ŭi munhwa chŏgŭng sŭt'ŭresŭ'wa taech'ŏ kijŏn 북한이탈주민의 문화적응 스트레스와 대처기전 [A Study on Acculturation Stress and Stress-coping among North Korean Defectors].” Sŏngin kanhohak hoeji 성인간호학회지[Korean Journal of Adult Nursing], 23 (1), pp, 50-59.

Kim, Soon Yang. 2010. "Tackling the Social Exclusion of the North Korean Refugees in South Korea." Korea Observer, 41 (1), pp. 93-129.

KOSEA. Korea Social Enterprise Promotion Agency. Online: http://www.socialenterprise.or.kr/eng/index.do (accessed: November 26, 2015).

Lankov, Andrew. 2006. "Bitter taste of paradise: North Korean Refugees in South Korea" Journal of East Asian Studies, 6 (1), pp. 105-137.

Lankov, Andrew. 2015. "The Real Reason North Korea Refugees - Not Defectors - Struggle". NK News, February 17, 2015. Online: http:/www.nknews.org/2015/02/the-real-reason-northkorea-refugees-not-defectors-struggle/ (accessed: May 16, 2015).

Lee, Ahlam. 2015. North Korean Defectors in a New and Competitive Society: Issues and Challenges in Resettlement, Adjustment, and the Learning Process. London: Lexington Books. 
Marsella Anthony J., Thomas Bornemann, Solvig Ekblad and John Orley, eds. 1994. Amidst Peril and Pain: The Mental Health and Well-Being of the World's Refugees. Washington, DC: American Psychological Association.

Nee, Victor, Jimy M. Sanders, and Scott Sernau. 1994. "Job Transitions in an Immigrant Metropolis: Ethnic Boundaries and the Mixed Economy.” American Sociological Review, 59 (6), pp. 849-872.

Oh, Ji Hyun. 2015. "Relationships Between Acculturative Stress, Depression, and Quality of Life on in North Korean Refugees Living in South Korea." Journal of Health Education Research and Development, 3 (142), doi:10.4172/2380-5439.1000142.

Park, Chan-ung. 2009. The Korean Model of Social Enterprises: A Comparison with European Experiences. Seoul: Yonsei University, Department of Sociology.

Porter, Matthew and Nick Haslam. 2005. "Predisplacement and Postdisplacement Factors Associated with Mental Health of Refugees and Internally Displaced Persons: A Meta-analysis [Review]." Journal of the American Medical Association, 294 (5), pp. 602-612.

Sanders, Jimy M. and Victor Nee. 1996. "Immigrant Self-employment: The Family as Social Capital and the Value of Human Capital." American Sociological Review, 61 (2), pp. 231-249.

Social Enterprise Promotion Act 2008. Ministry of Labour. Online: http://www.moleg.go.kr/main.html (accessed: November 26, 2015).

Sohn, Sang-Hee. 2013. "Living in a Consumer Society: Adaptation Experiences of North Korean Youth Defectors in South Korea." Asian and Pacific Migration Journal, 22 (1), pp. 109-131.

Sŏl, Chin-bae 설진 배, Song Ǔn-hŭi 송은희, and Yi Ǔn-mi 이은미. 2014. "Pukhan'i t'aljumin'ǔi sahoet'onghapangan: kyŏngje'jŏk chŏgŭngi simni'jŏk chŏgŭng'e mich'inŭn yŏnghyang 북한이 탈주민의 사회통합 방안: 경제적 적응이 심리적 적응에 미치는 영향 [Social Integration of North Korean Refugees in South Korea: The Effects of Economic Adaptation on Psychological Adaption]." Han'guk tongbuk anonch'ong 한국동북아논총 [Journal of NorthEast Asian Studies], 70, pp. 157-174.

van Tubergen, Frank. 2005. "Self-employment of Immigrants: A Cross National Study of 17 Western Societies." Social Forces, 84 (2), pp. 709-732.

Volery, Thierry. 2007. "Ethnic Entrepreneurship: A Theoretical Framework." In Léo-Paul Dana, ed., Handbook of Research on Ethnic Minority Entrepreneurship: A Co-evolutionary View on Resource Management. Cheltenham: Edward Elgar, pp. 30-41. Online: https://www.alexandria.unisg.ch/39658/ (accessed: February 9, 2018).

Waldinger, Roger, Howard Aldrich, and Robin Ward. 1990. "Opportunities, Group Characteristics and Strategies." In Roger Waldinger, Howard Aldrich, and Robin Ward, eds., Ethnic Entrepreneurs: Immigrant Business in Industrial Societies. London: Sage, pp. 13-48.

Wang, Bo-Ram, Shieun Yu, Jin-Won Noh, and Young-Dae Kwon. 2014. "Factors Associated with Self-rated Health Among North Korean Defectors Residing in South Korea." MC Public Health, 14: 999. Online: http://www.biomedcentral.com/1471-2458/14/999 (accessed November 9, 2015).

White Paper 2014. White Paper on Korean Unification. Seoul: Ministry of Unification. Online: http://eng.unikorea.go.kr/content.do?cmsid=1819 (accessed November 11, 2015).

Witzel, Andreas. 2000. The Problem-centered Interview. Forum: Qualitative Social Research, 1 (1). Online: http://www.qualitative-research.net/index.php/fqs/article/view/1132/2519 (accessed November 9, 2015).

Yi, Ch'an 이찬, Yi Yong-hwan 이용환, Yi Yun-jo 이윤조, Sin Chae-ho 신재호, Hong Yun-sŏn 홍윤선, and Ch'oe Hong-ju 최홍주. 2007. “Saet’ŏmin'ŭi kich'o chigŏp nŭngnyŏk chindan 새터민의 기초직업능력 진단 [Assessment of the North Korean Refugees' Basic Vocational Competencies].” Nongŏp kyoyuk'kwa injŏk chawŏn kaebal 農業教育斗人的資源 
開發 [Journal of Agricultural Education and Human Resource Development], 39 (3), pp. 213238.

Yun, In-jin 윤인진 and Yi Chin-bok 이진복. 2006. "Sosuja'ŭi sahoe'jŏk paeje'wa sahoe t'onghab'ŭi kwaje: pukhani chumin'ŭi kyŏnghŏm'ŭl chungsim'ŭro 소수자의 사회적 배제와 사회통합의 과제: 북한이 주민의 경험을 중심으로 [Social Exclusion and Social Integration of Minorities: The Experience of North Korean Migrants]." Han'guk sahoe 한국사회 [Korean Society], 7 (1), pp. 41-92.

Yun, In-chin 윤인진. 2000. “T'albukcha'ŭi charip chŏngch'ag'ŭl wihan chajo model: chayŏngŏp kiban hyŏngsŏng’ŭl chungsim'ŭro 탈북자의 자립정착을 위한 자조모델: 자영업 기반형성을 중심으로 [Self-employment in Business of North Korean Defectors in South Korea]." Koryo University: Asiatic Research Center, pp. 143-287.

\section{ABBREVIATIONS}

KRW

$\mathrm{NKRF}$

OECD

PTS

SK

NK

SME

WEST
Korean Won

North Korean Refugees Foundation

Organisation for Economic Co-operation and Development

Post-traumatic Stress

South Korea

North Korea

Small and Medium Enterprise

Work, English Study and Travel

\section{GLOSSARY}

\begin{tabular}{|c|c|c|}
\hline Haenyŏ & 해녀 & Female diver \\
\hline Hamgyŏngdo & 함경도 & Region in North Korea \\
\hline Hanawŏn & 하나원 & $\begin{array}{l}\text { Settlement Support Centre for North Korean } \\
\text { Refugees }\end{array}$ \\
\hline Inmaek & 인맥 & Personal connections \\
\hline Saet'ömin & 새터민 & North Korean defector or new settler \\
\hline Pukhani t'aljumin & 북한이탈주민 & North Korean defector or new settler \\
\hline T'albukcha & 탈북자 & North Korean defector or new settler \\
\hline Tojŏn chŏngsin & 도전 정신 & Challenge spirit \\
\hline Yŏmyŏng hakkyo & 여명학교 & Yŏmyŏng Highschool for North Koreans \\
\hline
\end{tabular}


82 Vienna Journal of East Asian Studies 